\title{
Pulmonary Aspergillosis
}

\author{
Jan Susilo
}

\begin{abstract}
Abstrak
Aspergillus dapat menimbulkan kelainan melalui tiga cara yaitu sebagai agen toksik, sebagai alergen atau sebagai patogen. Aspergillus sebagai agen toksik tidak berlaku pada aspergilosis paru karena kelainan hanya terdapat di paru sedang aflatoksin, yang ditimbulkan oleh Aspergillus yang tumbuh pada hasil pertanian, menimbulkan kelainan hepatoma bila cukup banyak termakan. Untuk membedakan apakah Aspergillus bertindak sebagai alergen atau sebagai patogen, perlu dilakukan pemeriksaan adanya imunoglobulin spesifik terhadap Aspergillus dan biopsi paru. Tetapi tindakan diagnostik tersebut tidak dilakukan karena mahal dan sulit dilakukan. Deteksi Aspergillus dalam sputum atau bilasan bronkus dan pemeriksaan serologi dapat membantu menentukan apakah Aspergillus berperan dalam timbulnya gejala dan keluhan. Untuk mencapai diagnosis aspergilosis paru perlu adanya 1) kesadaran akan kemungkinan adanya penyakit tersebut, 2) pengetahuan pengambilan bahan klinis dan cara pengiriman ke laboratorium, 3) keahlian dalam pemeriksaan bahan klinis oleh teknisi laboratorium dan 4) keahlian dalam pemeriksaan serologi. Diagnosis sulit dipastikan bila tidak terdapat laboratorium mikologi di rumah sakit bersangkutan atau laboratorium tersebut terletakjauh dari rumah sakit. Sub Bagian Mikologi, Bagian Parasitologi, Fakultas Kedokteran Universitas Indonesia yang merupakan salah satu dari beberapa laboratorium yang melakukan isolasi dan identifikasi jamur, melakukan pemeriksaan serologi dan sediaan patologi untuk kemungkinan mikosis. Pada umumnya pemeriksaan mikologi jarang dilakukan dan mikosis lebih sering ditemukan secara kebetulan pada pemeriksaan patologis. Makalah ini mengemukakan diagnosis dan penanggulangan aspergilosis paru para penderita yang dikirim ke Sub Bagian Mikologi, Bagian Parasitolologi, Fakultas Kedokteran Universitas Indonesia yang pada hakekatnya merupakan pasien terbanyak yang ditemukan di Indonesia hingga saat ini.
\end{abstract}

\begin{abstract}
There are three possible mode that Aspergillus could act as a disease agent, namely as a toxigenic, allergenic or pathogenic agent. Aspergillus as a toxigenic agent could not be applied in aspergillosis of the lung as the lesion are confined to the lungs while aflatoxin, which is produced by Aspergillus in agricultural products, will induce hepatoma if ingested adequately. To differentiate whether Aspergillus act as an allergenic or pathogenic agent, detection of specific immunoglobulin against Aspergillus and biopsy of the lung should be carried out. These diagnostic procedures, however, may not be cost effective or could not be done for practical reasons. Detection of Aspergillus in sputum or bronchial washing and serological examination may help determine whether Aspergillus play a part in the development of the clinical signs and symptoms. To reach the diagnosis of aspergillosis of the lung there should be 1) awareness of the possibility of the disease, 2) knowledge of collection and sending of clinial specimens, 3) expertise in the examination of the clinical specimens by the laboratory technicians and 4) expertise in serological examination. Confirmation of the possible diagnosis may be difficult if there is no mycology laboratory in the hospital or within reasonable distance from the hospital. Generally no mycological examinations were taken into account and mycoses were more often detected by chance during pathological examination. The Mycology Section of the Department of Parasitology, Faculty of Medicine University of Indonesia is one of the few mycology laboratories that isolates and identifies fungi, does serology and examines pathological slides for the possibility of mycotic infection. This paper reports the diagnosis and management of aspergillosis of the lung cases referred to the Mycology Section of the Department of Parasitology, Faculty of Medicine University of Indonesia, which in essence were most of the cases found so far in Indonesia
\end{abstract}

Keywords : Aspergillosis. Lung. Diagnosis. Management.

\section{INTRODUCTION}

Aspergillus is a ubiquitous fungus that grows almost anywhere in tropical climate which is optimal for the

Department of Parasitology, Faculty of Medicine, University of Indonesia, Jakarta, Indonesia

Invited lecture at the Symposium: "Medical Mycology:

Clinical and Therapeutic aspects" in the 5th Medical

Mycology Course held at the University of Santo Tomas,

Manila, The Philippines, April 4-27, 1995 growth of this fungus. ${ }^{1,2}$ Aspergillus plays a role in the ecosystem in changing organic into inorganic matter which is needed for the growth of plants. Although it plays a role in the biodeterioration of organic matters, it could also be used in the synthesis of industrial enzymes and food fermentation e.g. in the production of soybean ketchup. ${ }^{3}$

Its role in biodeterioration explains also its part as a disease agent. There are three possible modes as a disease agent, i.e. toxigenic, allergenic and pathogenic. 
As a toxigenic agent it produces aflatoxin, a mycotoxin, when it grows in food and other agricultural products. Aflatoxin could induce hepatoma when ingested adequately. Examination of liver biopsy from patients with hepatoma showed traces of aflatoxin. ${ }^{4}$ As an allergenic agent, it induces allergic reaction in the respiratory tract when its spore or fungal elements are inhaled, manifesting as an asthmatic syndrome. ${ }^{5}$ Detection of immunoglobulin specific against Aspergillus will verify this possibility. In allergic bronchopulmonary aspergillosis, besides the asthmatic syndrome, IgG against Aspergillus is also detected, showing a certain degree of infiltration of the fungus into the lung tissue. Most frequently we face Aspergillus as a pathogenic agent. Finding fungal elements in the tissue will confirm the diagnosis.

Aspergillus can infect the skin, nail, cornea, sinus or internal organs, especially the lungs. It is frequently encountered as one of the causative agent in systemic nosocomial or secondary infections.

Aspergillosis of the skin and nail can be easily determined by direct examination and culture of skin and nail scrapings. Aspergillosis of the cornea and sinuses can also be easily detected by examination and culture of corneal scraping and discharge from the sinuses. Aspergillosis of the lung, on the other hand, as any other systemic mycosis, can not be differentiated clinically from other diseases of the lung. This disease can be a primary or more often a secondary or nosocomial infection. ${ }^{6,7,8,9}$ Its signs and symptoms are not specific. Diagnosis can be achieved if there is 1) an awareness of the possibility of Aspergillosis, 2) knowledge of appropriate collecting and sending of clinical specimens, 3) expertise in examination of clinical material by the laboratory technicians and 4) serological examinations. After confirmation of the diagnosis, treatment can be initiated.

As pulmonary infection caused by virus and bacteria are common in Indonesia and other tropical countries, notably when environmental health is poor, main attention of the examining physician is drawn to these possibilities. ${ }^{6}$ If the suspected diagnosis can not be confirmed by laboratory methods or if treatment to the primary disease does not give satisfactory results, then the possibility of mycotic infection will be considered. Within this framework, there were not many cases suspected or examined for the possibility of this disease in Indonesia. More often, aspergillosis of the lung was diagnosed by chance during tissue examination after surgery. ${ }^{6}$
Another confounding factor is the lack of mycology laboratory to support or confirm the diagnosis. The Mycology Section of the Department of Parasitology, Faculty of Medicine, University of Indonesia is one of the few laboratories that isolate and identify fungus from clinical specimens, does fungal serology and examine pathological slides for mycoses.

This paper reports the detection and treatment of aspergillosis of the lung referred to the Mycology Section of the Department of Parasitology, Faculty of Medicine University of Indonesia. As there were not many cases of aspergillosis detected and reported, although cavity with fungus ball were frequently seen in chest $\mathrm{X}$ - ray, these cases in essence were most of the patients so far detected and confirmed in Indonesia.

\section{MATERIALS AND METHODS}

Patients included in this research were cases with abnormal chest $\mathrm{X}$-ray, with clinical signs and symptoms i.e dyspnea, chest pain or discomfort, cough or hemoptea referred to the Mycology Section of the Department of Parasitology, Faculty of Medicine University of Indonesia. Most of these patients were from other hospitals in Jakarta. These patients had been treated with antibiotics without apparent improvement. Others were sent from different parts of Indonesia with the same problem. Sputum or bronchial washing from hospitalized patients was sent in sterile petri disc or tubes. Acid fast bacteria were not found in the sputum or bronchial washing. These specimens were examined directly for fungal spore or hypha and cultured on Sabouraud dextrose agar. Serological examination were done utilizing the immuno - diffusion method (Oughterlony method) . Patients with Aspergillus isolated from their clinical materials and or positive serology were treated with oral itraconazole.

Initially, as most of the patients body weight were between $45-55 \mathrm{~kg}$, the patients were treated with 100 $\mathrm{mg}$ itraconazole, single dose, daily. This dose was increased to $200 \mathrm{mg}$ if there is no adverse reaction after three days of treatment and was given for two months.

Patients were considered improved if there is alleviation of the signs and symptoms, the lesion in the chest $X$ - ray diminished or cured if the lesion disappeared, serological examination became negative and Aspergillus could not be isolated from the clinical specimens. 


\section{RESULTS}

From 24 patients with abnormal chest X - ray, 20 with infiltrate and 4 with cavities containing fungus ball, Aspergillus were isolated from sputum or bronchial washing. Twenty two of these patients showed positive serology against Aspergillus by the immuno-diffusion method. One patient with infiltrate and one patient with cavity and fungus ball were serologically negative. Eighteen patients with infiltrate in the lung were cured and two improved after two months of treatment. One patient with cavity and fungus ball was cured (Fig. 1,2) and three patients with cavities and fungus ball were improved. One of these improved patient, who also had destroyed right lung, died after massive hemoptysis one month after completion of treatment (Table 1).

Table 1. Chest X-ray, serology and treatment results of 24 patients with Aspergillus isolated from their sputum and/or bronchial washing

\begin{tabular}{crrrll}
\hline No Patients & Infiltrate & Cavity & Fungus ball Serology & Result \\
\hline 18 & + & - & - & + & Cured \\
2 & + & - & - & - & Improved \\
2 & + & + & + & + & Improved \\
1 & + & + & + & + & Cured \\
1 & + & + & + & - & Improved
\end{tabular}

* One patient with destroyed lung and infiltrates improved, but died one month after completion of treatment due to massive bleeding.

\section{DISCUSSION}

As mentioned in the introduction, there are three possible way that Aspergillus may create problems in human. Clearly, Aspergillus as a toxigenic agent could not be possibly applied in this group of patients as their signs and symptoms were localized in the lung or respiratory tract. Two other possibility remain namely as an allergenic or pathogenic agent.

As an allergenic agent, especially if there is a bacterial superinfection, the fungus may induce signs and symptoms that were found in these group of patients. Immunoglobuline specific against Aspergillus was not examined, as it is expensive to do and is not cost effective for the management of the disease. To prove that Aspergillus was the causative or pathogenic agent in these group of patients, a biopsy of the lung tissue in the affected area should be carried out, which was not done in this study for practical reason.

Although not specific, changes in clinical signs and symptoms of the primary disease could lead us to the suspicion of a possible fungal infection.
Since dramatic or rapid improvement of the symptoms were observed after treatment, Aspergillus must have played an important role in the pathophysiology of the disease, which justify the treatment.

To know the significancy of this assumption, further trial, comparing the treated and untreated group with itraconazole, should be carried out.

As Aspergillus is ubiquitous, prophylaxis treatment in immunocompromised patients has been suggested. ${ }^{10}$ This should be seriously contemplated as immunocompromised patients are weak persons and antimycotics are not without side effects. Moreover, prophylactic treatment, if given inadequately, may easily lead to resistancy as have been increasingly reported in candidosis.

Itraconazole should be substituted with Amphotericin - B if there is no improvement or the symptoms deteriorate.

\section{SUMMARY AND CONCLUSION}

Aspergillosis of the lung is difficult to diagnose as its sign and symptoms, like other systemic mycosis, are not specific.

As tropical climate is optimal for the growth of Aspergillus and other fungi, the possibility of Aspergillus as a disease agent should be considered, notably in lung infections.

Aspergillus isolated from sputum or bronchial washing should be seriously considered as a possible disease agent as this fungus could induce allergic or pathological changes.

Treatment of aspergillosis with oral antimycotic is convenient and the patient could be treated at the out-patient clinic.

Prophylactic treatment should be seriously contemplated as this could lead to resistance of the fungus against the antimycotic used.

\section{REFERENCE}

1. Rippon JW, Medical Mycology. 3rd ed. Philadelphia. London.Toronto; W.B. Saunders Company. 1988.

2. Seeliger HPR, Tintelot K. Epidemiology of Aspergillosis. In: Vanden Bossche H, Mackenzie DWR and Cauwenbergh G, editors. Aspergillus and Aspergillosis. New York and London: Plenum Press, 1988, 23-34. 
3. Mackenzie DWR. Mycoses in relation to Health for all by the year 2000. In: The Indonesian Society for Human and Animal Mycology. Scientific Meeting. Medical and Veterinary Mycology current problems and its management. Faculty of Medicine, University of Indonesia. Jakarta. 1989. (Temu Ilmiah: Masalah Mikologi Kedokteran Manusia dan Hewan Masa Kini dan Penanggulangannya. FKUI, Jakarta. 1989).

4. Pang RTL. The role of Aflatoxin in primary liver cancer. Proceeding. Third Asian Cancer Conference.Manila, Philippines. 1977.

5. Hay RJ. Pulmonary Aspergillosis. The Clinical Spectrum. In: Vanden Bossche H, Mackenzie DWR and Cauwenbergh G, editors. Aspergillus and Aspergillosis. New York and London: Plenum Press, 1988: 97-106.

6. Susilo J. Diagnosis Laboratoris Mikosis Paru. Proceeding (in press) Laboratory Diagnosis of Lung Mycosis. VI National Congress of the Indonesian Pulmonologist Association.
Surakarta; 1993. (KONAS VI Perhimpunan Dokter Paru Indonesia; Surakarta, 1993).

7. Susilo J. Infeksi Nosokomial. Diagnosis dan Penanggulangannya. Simposium Mikologi. Palembang 1993. (Nosocomial Infection. Diagnosis and management. Mycology Symposium. Palembang 1993 ).

8. Richardson RG. Opportunistic Fungal Infection. International and Congress Series Number 153,. London. New York: Royal Society of Medicine. Services limited, 1989

9. Susilo J. Pengobatan mikosis sistemik dengan amfotericinB. Majalah Perhimpunan Ahli Mikrobiologi Klinik Indonesia. Nopember 1987: 21-3. ( Treatment of systemic mycosis with Amphotericin - B. Journal of the Indonesian Society for Clinical Microbiology. November 1987: 21-3).

10. Cauwenbergh G. Prophylaxis of Aspergillosis in immunocompromised patients. In: Vanden Bossche $\mathrm{H}$, Mackenzie DWR and Cauwenbergh G, editors. Aspergillus and Aspergillosis. New York and London: Plenum Press, 1988:283-8. 